\title{
Academic and Artistic Freedom and the Israel-Palestine Conflict: Towards a Canadian Pedagogy of the Suppressed
}

\author{
Len Findlay \\ University of Saskatchewan \\ len.findlay@usask.ca
}

\begin{abstract}
In this essay I argue that the suppression and discouragement of teaching and discussion relating to the Israel-Palestine conflict can and should be countered by a pedagogy rooted in the most robust traditions of academic freedom and inspired by the most challenging practices and products of artistic freedom. Freedom of inquiry, imagination, and exchange are essential to the analysis of current realities and the capacity to envisage them otherwise. This is especially true in the current chilly climate where the asymmetries of power, resources, and communicative clout are most pronounced--or, to put it more colloquially, in situations where the playing field is least level and where academic and artistic freedom are most needed and most at risk. Such asymmetrical power relations are especially evident (as well as subtly coded) in the playing out and playing off of the Israel-Palestine conflict in the United States and Canada, thanks to the intimidation, amnesia, and gross simplifications that have strengthened their hold on public discourse in both countries since $9 / 112001$. The unconditional support extended to Israel by the George W. Bush administration as a key part of the so-called "war on terror" has been eagerly imitated by Stephen Harper's government and disappointingly reinforced in November 2010 in the so-called Ottawa Protocol on Combating Anti-Semitism (O’Malley, 2010).
\end{abstract}

In a context so officially pro-Israel as Canada today, how can readers of the Journal of Cultural and Pedagogical Inquiry use their academic freedom and commitment to artistic freedom to document and discuss the realities of the Israel-Palestine conflict and to imagine them otherwise? Which works of the imagination might teachers call on to assist them and their students to win through to a fairer and more innovative approach to a situation whose apparent hopelessness favours the status quo and therefore continues to disadvantage Palestinian people in horrendous, often illegal ways? What homework is required of educators before they can undertake this task with even the dimmest prospect of the most modest success? I attempt to answer these questions in five steps: beginning with a sketch of academic freedom, the sine qua non for any pedagogy of the suppressed; examining how that freedom was threatened in a case bearing directly on the Israel-Palestine conflict; connecting academic freedom under siege to artistic freedom constrained by the shadow of the Holocaust in the case of two iconic Canadian artists who might seem untainted by suppression of any sort, Alex Colville and Yann Martel; and concluding with a few suggestions about what might be considered and done to combat antiPalestinian prejudice in Canada today. I alternate deliberately here between sobriety and provocation, careful analysis and unfinished business, hoping that this mix will be emulated by others in their own way but for a common end, as readers of and contributors to this special issue

Cultural and Pedagogical Inquiry, 2010, 2 (2), Special Issue, pp.5-18

ISSN 1916-3460 () 2011 University of Alberta

http://ejournals.library.ualberta.ca/index.php/cpi/index 
attempt to re-conceive, implement, and share practices that will more openly and effectively teach the Israel-Palestine conflict.

\section{Academic Freedom: History, Scope, and Current Importance}

The modern development of academic freedom has philosophical roots in the German Enlightenment and in the slightly later emergence of the modern research university with the founding of the University of Berlin by Wilhelm von Humboldt in 1810. From the outset, the democratizing impulse behind new investigative, pedagogic, and expressive freedoms was intermittent and embattled. Theology did not readily give up its grip on university resources, rituals, values, and outcomes, while the political establishment feared and disciplined scholars whose work openly or implicitly broached the possibility, desirability, or inevitability of radical social change. Elaborate balancing acts and strategic obscurantism and self-censorship were required by those who wanted a fuller academic freedom without incurring dire consequences for themselves, their students, and their host institutions. The locus classicus for such mixing of prudence with principle remains Immanuel Kant's The Conflict of the Faculties (1798). Academic freedoms derived from the Kantian tradition spread slowly across Europe and North America, testifying en route to the fact that they were born in compromise and raised in circumspection (and largely unexamined sexism and heterosexism), incrementally establishing and strengthening links between economic prosperity, political stability, and unregulated inquiry and exchange.

It would be too simple to say that the growth of academic freedom is identical with the extension of the franchise in Western societies, but that is roughly what happened and continues to happen. However, just as not everyone who is entitled to vote does so, many of the faculty entitled to exercise their academic freedom do so only intermittently and complacently, except when threatened by circumstances directly affecting their own careers. Nonetheless, the links between democracy and academic freedom remain robust and are reliable indicators of the state of any nation at any particular time. After all, higher education remains a field driven by tensions and contradictions as well as a site onto which is projected the dreams and aspirations of ordinary women and men and the presumptions of traditional and emergent elites.

In Canada, our college and university system is distinctive but strongly marked by the colonial legacies of France and Britain, and by our geographical proximity to the United States. Public understanding of, and enthusiasm for, publicly funded, autonomous universities where faculty enjoys academic freedom is highly variable, especially at times when patriotism drowns out principle, and dissenting voices (like Sunera Thobani's, for example) are criticized as disloyal. As for the legal protections afforded Canadian universities and their academic staff, these are mixed. Unfortunately, there is not as much jurisprudence on this matter as there ought to be. But this at least is clear. The Harry Crowe case is pivotal, not least because it led to the establishment of the Canadian Association of University Teachers (CAUT)). Also key is the case of McKinney versus University of Guelph (1990), a case that went all the way to the Supreme Court of Canada on behalf of eight professors and an academic librarian who were protesting the policy of mandatory retirement in Ontario universities. In the course of their deliberations on age and academic competency, the Supreme Court Justices made some invaluable and influential observations and claims. For example, as far as institutions' autonomy is concerned, "it is fully 
buttressed by their traditional position in society" (McKinney, 1990, unpaginated). Moreover, universities and colleges should be confident in their present and future because "academic freedom and excellence is necessary to our continuance as a lively democracy" (McKinney, 1990, unpaginated). What dissenting Justice Mme. L'Heureux-Dubé terms "the historical approach" and "the functional approach" alike attest to the fact that "Canadian universities have always fiercely defended their independence" (McKinney, 1990, unpaginated). This arguably oversanguine view leads to the more solid recognition of tenure as providing "the necessary academic freedom to allow free and fearless search for knowledge and the propagation of ideas" (McKinney, 1990, unpaginated). Despite the fact that "the state exercises a substantial measure of control over universities in Canada" (McKinney, 1990, unpaginated) through funding, statutes defining governance, judicial review and rights of approval over some academic policies and programs, the cumulative effect of the Justices' observations is to establish the need for, and benefits resulting from, the respecting of institutional autonomy and academic freedom through open charters and tenure. There is an association of debate and dissent with both democratic vitality and intellectual excellence, in a configuration of rights and responsibilities deserving of regular re-affirmation, especially in times of controversy or crisis, and especially when an initiative like the Ottawa Protocol on Combating Antisemitism endeavours to control how the Israel-Palestine conflict is taught while seeming to recognize "freedom of speech and the principle [if not the practice] of academic freedom" (O’Malley, 2010, p. 4).

Academic freedom has not been, and cannot be, impervious to change. It is, rather, historically contingent and variable across cultures, experiencing even a "roller-coaster history" (Doumani, 2008, p. 13). From this reality we can derive both hope and apprehension: hope that we can preserve and improve the current protections afforded by it, and apprehension lest current protections are significantly abridged or disappear altogether for some or all academic staff. Academic freedom is therefore a site for ongoing activity, not an immutable sanctuary to which to appeal or retreat when difficulties arise. It is a pedagogical site for recurrent self-education and the generation of fresh understanding of its provisions and possibilities by academic staff, their disciplines, and their organizations, and the sharing of that understanding with university and college administrators, policy makers, the media, and the general public. Academic freedom needs and rewards regular testing of the adhesive aptness of this "glue that holds the university together, the principle that protects its educational mission" (Nelson \& Watt, 1999, p. 22).

\section{A Teachable Moment at York University: Israel- Palestine and Academic Freedom Under Siege}

The links between academic freedom and the Israel-Palestine conflict have been clear ever since the establishment of the State of Israel, because this conflict has been among other things a war of academic ideas and reputations, competing histories, geographies, archaeologies (Silberstein, 1999; Rogoff, 2000; \& Abu El-haj, 2001). Interest has fluctuated, physical violence ebbed and flowed, passions flared and subsided, while deficiencies on both sides have been tirelessly documented and fearlessly critiqued by scholars like Edward Said (Said, 2001; Said, 2004). Said's contributions were made even more noteworthy because he was based in the 
United States, at Columbia University in New York City, and was constantly under siege from the Zionist academy and media as well the outliers of Arafat and the PLO. Said occupied the place of exemplary public intellectual and critical humanist, attracting fire from all sides for his work on and for Palestine while remaining undeterrable and inspirational in putting his foundationally postcolonial work on orientalism to work in post-naqba politics and material culture alike (Bell \& Findlay, 2010). He was joined in that space by remarkably diverse supporters, including Jewish luminaries like Jacqueline Rose and Daniel Barenboim, but academic faction has so far proved much more powerful and pronounced than peacemaking and re-imagining, especially in the United States.

Britain's greater intellectual and political willingness to seek a proportionate response to a difficult problem gave rise in time to initiatives that have had major repercussions in Canada, most notably perhaps, the proposal by some British academics in 2007 to have their University and College Union consider a boycott of Israeli universities (see BRICUP website for a large archive and regular updates. ${ }^{1}$ ) The key features of the boycott story in the Canadian context are the remarkably uniform and apparently orchestrated responses of university presidents across the country ( 24 of them in my informal archive), the appeals to academic freedom at the heart of most of these responses, and the impact such public statements by university leaders had on their local communities as members of those communities planned and participated in initiatives such as Israel Apartheid Week, which has been marked on Canadian campuses in various ways during the first week in March each year since 2005. Not surprisingly, the administrative tendency to oppose the boycott converged with the desire to preserve institutional reputation or "brand" by severely policing student activists and their faculty and community public supporters. The effect has been highly hypocritical, with administrators claiming academic freedom for themselves and their colleagues and students while subverting the academic freedom of those within their own communities who insist on the rights of their Palestinian counterparts and the constituencies they attempt to serve in the West Bank and Gaza (Findlay, 2009).

This troubled history provides the backdrop to events leading up to and from a now infamous conference in 2009 planned by law faculties at Queen's and York universities as part of the $50^{\text {th }}$ anniversary of the founding of York. The conference was eventually entitled, as a result of intense lobbying and principled conciliation, Israel/Palestine: Mapping Models of Statehood and Paths to Peace (see Drummond, forthcoming). The story of this conference will no doubt be told and retold over the coming years as it becomes even more fully recognized as a parable of academic idealism and vulnerability, indeed a supremely teachable moment. The most authoritative guide so far to this affair is Professor Susan G. Drummond of Osgoode Hall Law School at York, who was one of the four key organizers of the conference. She has written a compelling account of events in a book manuscript (which I have read) currently under consideration by the University of British Columbia Press, and she is also the main force behind the "Fragile Freedom at YorkU.ca" website which has invaluable background and provocative considerations of the state of academic freedom at her university. ${ }^{2}$ Professor Drummond's main findings are that there were concerted attempts to violate the academic freedom of the conference

\footnotetext{
${ }^{1}$ BRICUP is the British Committee for the Universities of Palestine. http://www.bricup.org.uk/

${ }^{2}$ See http://www.fragilefreedomatyorku.ca?
} 
organizers, attempts coming from both inside and outside York university from people who wished to derail the event or at least prevent it from happening on the premises of a major Canadian university and under the aegis of two leading Canadian law schools. The forces and methods at work as conference planning got seriously underway with commendable levels of openness and sensitivity, were much the same as those documented by John Mearsheimer and Stephen Walt (2007)in their book, The Israeli Lobby and U.S. Foreign Policy, a magisterial work for which these two distinguished American scholars were demonized and shunned. The organizers of the Mapping Models conference were told in no uncertain terms that they had no right to be doing this, that they had no scholarly basis on which to analyse or frame debate on the Israel/Palestine conflict, that what they were doing would damage a York University "brand" already besmirched by student activism and labour unrest, and that they would alienate current and potential donors to the university that employed them. The list of such grievances goes on and on, but they all have been, or soon will be, refuted by Professor Drummond and fellow members of the organizing committee, with able assistance from colleagues at Osgoode Hall and across the York campus.

The degree of complicity of York's senior administration with pro-Israel forces inside and outside the university is evident in the commissioning of former Supreme Court Justice Frank Iacobucci to research and write a report (Iacobucci, 2010) on events around the conference and implications for the future of academic freedom at York. This initiative, and its outcome have been roundly condemned for sins of omission and partiality. Particularly impressive in its critique of the collegial basis for adopting this course and for the highly selective interest and receptivity evinced by Mr. Iacobucci and his research assistants is a letter on behalf of the Law Faculty of Osgoode Hall available on the "Fragile Freedom" website (Gilmour et al., 2010). It is an impressive display of collective acuity and courage, especially when the author of the report being critiqued is so eminent a jurist. The Mapping Models conference had been held from June 22 to 24, 2009. In July 2009, President Shoukri appointed Mr. Iacobucci to advance what became an increasingly transparent attempt at damage control. The Osgood Hall academics rehearse what followed, skewering the senior York administration and their counsel-rapporteur as they go. The first of the Law faculty's conclusions is the following: "It is our position that the Iacobucci Report is fundamentally flawed on procedural and substantive grounds and that it should be rejected in its entirety. We urge Senate to do so. We also urge the university administration to honour its commitment to academic freedom by withdrawing the Report" (Gilmour et al., 2010, p. 3). The third conclusion contains a further demand: "We request that there be no further scrutiny of the conference organizers, who have been subjected to extensive and unwarranted scrutiny of their academic activities by York officials or their appointees for more than a year" (Gilmour, et al., 2010, p. 3).

Of course it takes more than incontrovertible evidence and rigorous reasoning to shame an administration into doing the right thing. "The University", as administrations like to term themselves, is still in defensive mode while contemplating new restraints on academic freedom in the name of academic responsibility. If the manual of best practices that Mr. Iacobucci recommended York produce turns out to be of the same quality as his own Report, then a 
particular and painful episode in the Canadian history of the Israel-Palestine conflict will not become the teachable moment it should be, but will instead endure as another sorry tribute to the exceptionalist bullying and silencing practiced by some who think they are defending Israel while they are in fact damaging it further in the eyes of its many critical but sincere supporters, such as those active in organizations like Canadians for Peace and Justice in the Middle East (see CJPME website). ${ }^{3}$

Fortunately, Mr. Iacobucci's is not the only report undertaken on this matter. CAUT has charged Professor Jon Thompson, one of three investigators of the Nancy Olivieri case, (Thompson, Baird, \& Downie, 2005) to do his own investigation. Professor Thompson has been receiving submissions from a wide range of parties and his Report is expected to be completed shortly and scheduled for publication as a book by CAUT. This initiative is consistent with CAUT's vigilance and its vocal opposition (in contrast to the demure silence of AUCC) to the attempt by Minster of State (Science \& Technology) Gary Goodyear to have the Social Sciences and Humanities Research Council (SSHRC) review planning for the Mapping Models conference which had received a ringing endorsement during the peer review process before securing SSHRC funding (Pinchin, 2009). CAUT's commissioning of an Independent Inquiry at York is consistent also with the organization's earlier stands on the military targeting of Israeli and Palestinian universities and colleges. It is also consistent with the work of David Robinson, an Associate Director at CAUT, who completed in November 2009 for CAUT and Brussels based Education International a study entitled The Status of Higher Education Teaching Personnel in Israel, the West Bank and Gaza. Unfortunately, this invaluable study has not received the attention it deserves. It reveals much the same the mix of internal and external challenges to academic freedom in both Israeli and Palestinian universities that we saw at York University. Moreover, Robinson's Report implies that academic staff across the region could and should be showing common cause and the transnational academic solidarity of which Canadian university presidents spoke while almost all of them were siding with Israel against a boycott of its institutions and ignoring appeals for solidarity from their Palestinian fellow-presidents.

Robinson finds that while Israeli universities have to face threats to collegial governance and the creeping militarization of the academy within what amounts to a national-security state, Palestinian institutions face regrettable silence on the matter of academic freedom, severe constraints on those civil liberties without which people and ideas cannot circulate as freely as they should, and physical security and funding challenges which dwarf those faced in Canada.

From this brief visit to Israel-Palestine relations as a site of academic contestation, it seems reasonable to conclude that the most reliable guardians of academic freedom are those who exercise it from below and from the margins rather than those who appeal to it from on high in the name of leadership and the right to speak for the university as a whole, or for universities worldwide. Academic staff and students prepared to broach difficult topics and dispute what they take to be half-truths and hegemonic lies should be applauded, not vilified and silenced.

\footnotetext{
${ }^{3}$ See http://cjpme.org/
} 


\section{Academic Freedom Looks to the Arts}

As we have seen, the current mania for branding and positioning in Canadian universities has led to an official intolerance of "straying" by faculty from safe topics to hot ones, and from narrowly defined and aggressively policed notions of academic expertise. But straying is a crucial part of intellectual inquiry, effective teaching, and creative practice. Indeed, it is another name for innovation, though in our ultra-instrumental times a less lustrous one. And creativity of all sorts is especially important at moments of chilling, censure, and the imposition of taboos. For some, the visual arts, for example, have no "real" place in a "serious" university. For others, these forms of engagement, exploration, and bearing witness are key because of their testimonial powers and the vulnerability that attends its unencumbered exercise. Once again, academic managers and branders favour interference and defensiveness, while CAUT is exemplary in its recognition of and determination to protect and nourish vulnerable forms of academic freedom. That is why the CAUT "Statement on Academic Freedom" available on its website is supplemented by a statement specifically addressing "Academic Freedom and Artistic Expression". The arts occupy a site where misunderstanding is habitual, attempts to constrain expression and audience exposure recurrent and usually triggered by controversy or "bad" publicity. For CAUT, if there is to be any regulations concerning studio practices and the subsequent display or performance of artistic works [they] should be drawn up in consultation with academic staff members who are knowledgeable and experienced in the relevant artistic discipline. Any such regulations should be neutral with respect to content and media and should relate only to the time, place and manner of presentation. (CAUT, http://www.caut.ca/pages.asp?page=6\&lang1

University administrations retain some discretion over physical space, but the implication is clear that questions of security or appropriateness cannot be unilaterally appealed to in order to obstruct legitimate academic activity in the visual arts. Moreover, when such moves or more direct ones seem designed to impose tests of "propriety, ideology or religion ... academic staff members have a duty to resist such attempts" (CAUT, http://www.caut.ca/pages.asp?page=6\&lang1

One way to use this terrain of vulnerability - art is 'only' imaginary, and is prone to irresponsibility - is to employ a form like photography to resist condescension and censorship. However, such are the kinds of entitlement claimed by some in regard to the Israel-Palestine conflict that even an exhibition of photos like the ones currently travelling across Canada under the title Human Drama in Gaza have become a target as zealously pursued as the Mapping Models conference initiative at York. Would-be censors, like the authors of the Ottawa Protocol in their comments about "singling Israel out for selective condemnation and opprobrium .. [as] hateful and discriminatory" (2010, para. 4), end up tying themselves in semantic and legalistic knots while re-enacting the territorial travails of the West Bank, Gaza, and East Jerusalem on Canadian soil and in Canadian institutions. The Human Drama in Gaza exhibit opened in the

\footnotetext{
${ }^{4}$ See http://www.caut.ca/
} 
Cinéma du Parc in Montreal in mid-January 2010 to mostly positive reviews. It was sponsored by Canadians for Peace and Justice in the Middle East (CPJME), an intercultural, secular and ecumenical group including lots of students as well as members of Faculty for Palestine, and it featured work by a full range of photographers from across and beyond the Middle East. However, an attempt soon followed to close the exhibit down on the grounds that the building that housed it was designed for purely "cinemagraphic use" (Cohen, 2010). This venue has a tradition of showing socially activist work, but only this exhibit attracted the attention of the owners of the shopping mall, which houses the Cinéma. Moreover, this selective sensitivity, expressive punctilio, and legal chill came from sources only too familiar to the organizers of the Mapping Models conference. Once again the politics of representation are playing out in a way at more fitting in a totalitarian state than in a poster democracy like Canada.

Especially useful in making sense of this self-cloaking censorship is the work of Jewish Israeli academic and curator, Ariella Azoulay, a prominent participant in post-Zionist debates (Silberstein, 1999) and a courageous critic of Israeli policies towards Palestinians. Azoulay offers, before the fact of the Montreal dispute, a defence of the showing of still photos in a movie theatre with her insistence, in relation to images captured in the Occupied Territories, that such photos need to be watched just like movies for their dynamic and narrative properties: "One needs to stop looking at the photograph and instead start watching it" (Azoulay, 2008, p. 14). Azoulay's work engages with notions of ownership of images, the gendering of sexual violence, the resilience and resistance of "governed populations" (Azoulay, 2008, p. 24), and the opportunity and necessity for moving towards "citizenship without sovereignty" (Azoulay, 2008, p. 128) based in ethical spectatorship rather than theocratic discrimination. Azoulay's "citizen of photography", when faced with images from the Occupied Territories "would take part in the restoration of the photographic énoncé and its transformation into an emergency claim" (Azoulay, 2008, p. 145). As a Jewish Israeli citizen raised in a right-wing home, Azoulay critiques her own advantaged position, the policies of the Israeli state, and the self-dehumanziing conduct of members of the Israel Defence Forces. Teaching her work allows one to refuse state simplifications and the painting of Israel as an internally united, tiny victim of Arab hostility, a victim deserving of unconditional support from the governments and citizens of other democracies like itself. Azoulay takes realistic and documentary forms and returns them to a semiotics of struggle and the possibilities of human dignity beyond blind patriotism and (mostly) long-distance, feel-good solidarity from a comfortably distant and righteous Diaspora. Her work leaves a hiding place for no-one, and more potential common ground than is usually allowed on this ultra-contested terrain.

One of the things that Canadian educators can do in engaging creatively with the IsraelPalestine impasse is to supplement the kind of work Azoulay does with projections of our own reality onto the ostensible enigma of the Middle East. Prime Minister Stephen Harper may have claimed, at a meeting of the G8 countries in Pittsburg in September 2009 that "Canada has no history of colonialism" (Walia, 2009), thereby starting the accountability clock only at Confederation, and then ignoring the masssively colonial impulses behind the history of immigration in this country, but the nature and purpose of this re-whitening and self-exonerating narrative is haunted and interrupted by what Plains Cree scholar and artist Neal McLeod aptly terms "settler anxiety" (Mcleod, 2010, p. 62). What is happening in the Middle East is not happening only there; nor is it unfamiliar to students of the postcolonial and anti-colonial, as was 
made evident in American scholar Ann Laura Stoler's recent statement of support for the boycott, divestment, and sanctions movement aimed at Israeli colonialism (Stoler, n.d.). What Azoulay has done in Israel, Stolar has done as a reflexive citizen of Israel's most important and still insufficiently critical sponsor, Obama's United States. These examples pose for Canadian academics the question: "What should we do?" Well we should interrogate the conditions and consequences of our own citizenship and use our own disciplinary knowledge to push the human beyond its current distribution in mainstream media and politics. To do so means affirming connections between Palestinians and First Nations, Inuit, and Métis, between the road allowance people (Campbell, 1995) and the "road-map" allowance people, each confined legislatively, economically, and culturally to the margins and leftovers of a prosperous poster democracy, Canada and Israel respectively.

\section{Required Reading in the Shadow of the Shoah}

Of course, one of the major difficulties involved in engaging today with the current version of the Israel-Palestine conflict is posed by what happened to Jewish people in Europe at the hands of the Nazis and their far flung sympathizers. However, the events leading to and from the Holocaust cannot be off limits to all but a chosen few, lest these events become in effect ghettoized and less instructive and transformative than they ought to be. Many countries have a significant history of anti-semitism to live down, and Canada is no exception (Abella \& Troper, 1982). When Montreal receives a graft off Anne Frank's tree in Amsterdam, this seems more a tribute to Canada's role in liberating Holland from Nazi occupation, and of Canada's support for Israel, than a recognition of our openness to Jewish refugees during the 1930s. But, apparently, everything changed after the enormity of the Holocaust became known, changing in ways that altered the politics and ethics of representation forever, even as the cataclysmic massacres and expulsion al Naqba for the Palestinians was lost in guilt-laden or opportunistic enthusiasm for the founding of the State of Israel (Said, 2001).

The complexities of these histories, elisions, and suppressions might be explored through the example of a Canadian icon such as Alex Colville whose duties as an official Canadian war artist brought him to Bergen-Belsen in 1945 (Metson \& Lean, 1981; Burnett, 1983). What does the artistic imagination do in face of that? To do nothing is a dereliction of humanity as well as official duty. To do anything, is to perform the inadequacies of oneself and one's medium in a way that threatens to minimize or distort that which must be seen for what it is, but cannot be fully shown for what it was and will be. The young Colville did his best, too detached and realistic though that best proved for some compared to the work of his fellow war artist, Aba Bayefsky, who was more clearly "haunted by the holocaust" (Brandon, 2006, p. 55). But haunting takes many differently productive forms, and Colville, in his developing command of the banality of menace and the permeability of borders between the human and the animal, remained marked by and obliquely commemorative of his experience of the Nazi death camps. Colville's is an apt example of the self-critical yet imaginative embrace of inadequacy as testimony. But he is not my main choice of exemplum here, though his work can serve a Canadian pedagogy of the suppressed in revealing how even the most celebrated of artists can 
have aspects of their work devalued or ignored because it does not fit the dominant version of the Holocaust. However, my exemplum is another apparent stranger to suppression, Yann Martel.

Yann Martel has recently, very deliberately taken up the challenge that Colville inadvertently had to face. Martel (2010) has done so in a novel featuring a donkey, Beatrice, and a howler monkey, Virgil, as well as a writer like the author himself and an ex-Nazi-cumtaxidermist. This novel has attracted much negative reaction, especially outside Canada (Barber, 2010), revealing as it does the asymmetrical structures of ownership, allegiance, and intolerance in place today that help skew perceptions of the Israel-Palestine conflict in favour of the former. Martel's refusal of the Holocaust taboo and the idea of a discursive and modal (historical realist) monopoly on that topic accomplishes several things. He reveals the patterns of censorship and self-censorship that surround and regulate acceptable themes and modes of representation. He exposes and interrogates the way that history is written as silence, omission, disfigurement, as well as the painstaking reconstruction of simulacra of dead originals and how they lived. He suggests that enigmatic evil and its banal cousin can be understood to a degree in their original contexts, but must also be understood in ours, lest the traumatic past become a museum piece or solely taxidermic reconstruction. In offering a history of the present in factual and fictional registers, and in narrative, dramatic, essayistic, and bibliophantic modes, Martel multiplies forms of witnessing in order to preserve and invigorate our own capacity to bear witness as both endurance and experiment, a human burden and a humanizing imperative. He shows how the unimaginable can happen only when our imaginations are suspended or irreversibly extinguished, and how neither possibility is achievable though neither in itself could guarantee the end of humanly contrived abomination.

Early in Martel's novel we find, in a tale by Flaubert, (not coincidentally the doyen of fictional realism), redemption without remorse for "the massacre of animals" (Martel, 2010, p. 44), but this occurs only in a pre-reformation world where the miraculous offers a kind of default position. But is there an equivalent, the narrator wonders, in the modern world in Diderot's Jacques or Beckett's tramps? We have the shop front and technique of the Okapi taxidermy (seeking to mask a moral enormity), and the domestic intimacy of the authorial "home", where the contagion of rabies causes the death of two pets and the grief of their owners. Jesus wept. So do Beatrice and Virgil, Sarah and Henry (the fictionalized author). The human/animal nexus runs from the wonder of the birthing mother and her slippery son to the "bestiality" of Nazi adolescents and grown men. The later scenes of the novel are redolent of a modern allegory whose inner mysteriousness - the anagogic — is both insisted upon and to a degree dispelled. The world has always been, it seems, one great charnel house; but it is also, like language and life's simple pleasures, all we have, all there is to hand. In sum, in its interrogation and strategic refusal of difference, and in its dismantling of hierarchy, this is a brilliantly imagined and crafted work by an uppity non-Jewish colonial who must be proven a one-hit wonder and put in his place by custodians of the contemporary English-language canon. This is bibliographically a "flip" book, split in the middle and reversible. But in other respects it is not flip at all but a product of and tribute to the seriously playful ethical imagination. In expanding genocide to the carnivorous or merely wanton holocaust of animals induced by humans, this book is held together, literally and symbolically, by the "common spine" we readers share with other life forms. 
The fact that Beatrice and Virgil have died is never in doubt; it is the manner of their living, alone and together, that makes their story yield such a bounty of meaning and questioning. Like the Samuel Beckett on whom he so unflinchingly and unapologetically depends in this text, Martel, facing without facing down moral catastrophe and its horrifically sanguine routines, locates a residual affirmation in literature and the aesthetic imagination, in the experience of empathy and recoil, of puzzlement and recognition. You can understand "the Holocaust" as something more than a hole in time, a descent into inhumanity, by extending and distending the category of the holocaustic as such, shifting from an originally religious and now human-genocidal register to a more inclusive ecocidal one. The risks that Martel runs are prodigious and persistent, while the "solution" he comes up with precisely refuses finality, living on ambiguously in the associative auras of terms like "a twentieth-century shirt," connecting as it does to the venerable tradition of sweating of labour as well as to the sartorial marking of the massively doomed and the survivors of the camps.

The concluding "Games for Gustav" offer readers a further means of retrieving, by themselves inventing, parts of a lost story. Unlike the depleted contexts of the prisoner's dilemma in modern economics qua game theory, these games show the sharpness of logic and its limitations, its defiing aporias. The games are unclassified yet organized as a numbered series, revealing both the magic of numbers and their dehumanizing power. Each game requires you to project, to imagine the unthinkable, in order to play - but to do so with all the gravity of serio ludere, with all the productivity of homo ludens (Huizinga, 1970), whether as a slippery newborn or an implacably imaginative adult. The Beckett of Waiting for Godot is simultaneously inside and outside the Stalag of each boxed game, continuing to play variations on symbolic typography until the "end," which is represented by a blank box for the unlucky thirteenth game.

\section{Towards a Canadian Pedagogy of the Suppressed}

I have not done anything like full justice to the topics and texts discussed here. My aim has been rather to configure them in provocative proximity so as to encourage a pedagogy emphatically risky no matter how adroit, because of the asymmetyrical power relations that define and confine understanding and representation of the Israel-Palestine conflict, relations bigger than any individual scholar or artist. The pedagogy I am recommending and have tried more or less awkwardly to model here, requires a critical understanding and exercise of academic freedom in relation to artistic freedom, and a teaching of the conflicts which is institutionally reflexive, and open to the possibility that canonical figures and works can be read for vulnerability as well as entitlement, above all when it comes to the gentile artist dealing with the Shoah and/or the Israeli state which succeeded it. It is an oppositional, anti-racist pedagogy and insurgent culturalism grounded in the traditions of academic empowerment and seeking artistic assistance in imagining an unjust situation otherwise. In resolving to teach the IsraelPalestine conflict through its historical and contemporary mediations and power relations, the teacher cannot hope for and ought not to try for "balance." Justice is the better goal because more purposeful and more controversial - and because justice is owned by no-one and pursued by all, in the territory they stand on (always already colonial in Canada's case) as well as in the 
venues elsewhere that matter to them. But in retrieving and re-inflecting much that has been suppressed in the shadow of the Shoah, the pedagogue and her fellow teachers will find invaluable protections in academic freedom and common cause with artistic freedom and its endlessly unsettling outcomes. Neither form of freedom can be taken for granted; neither is a source of unanimity or uniformity; and neither offers sanctuary from internal conflict and external threat. These two forms of freedom do, however, model invaluable ways of insisting on the rights of the Palestinian people (and their analogues everywhere) while insisting that support for Israel is worthless or dangerous if automatic and unconditional. Support for both Israel and Palestine needs to be vocal, visible, critical, and pedagogic, starting in curricula and classrooms but not ending there. 


\section{References}

Abella, I., \& Troper, H. (1982). None is too many: Canada and the Jews of Europe 1933-1948. Toronto, ON: Lester and Orpen Dennys.

Abu El-haj, N. (2001). Facts on the ground: Archaeological practice and territorial selffashioning in Israeli society. Chicago, IL: University of Chicago Press.

Ahren, R. (2009, May). Canada minister blasts 'dangerous' leftist-Islamist anti-semitism. Haaretz.com. Retrieved from http://www.haaretz.com/hasen/spages/1081973.html

Azoulay, A. (2008). The civil contract of photography. New York, NY: Zone Books.

Barber, J. (2010, June 5). A debate over the limits of representation. John Boyne and Yann Martel will discuss a charge both have faced: Trivializing the Holocaust. Globe and Mail.

Bell, L., \& Findlay, L. (2010). Orientalism \& ephemera: Two states or one? West Coast Line, 63, pp. 48-59.

Brandon, L. (2006). Art or memorial? The forgotten history of Canada's war art. Calgary, AB: University of Calgary Press.

Burnett, D. (1983). Colville. Toronto, ON: Art Gallery of Ontario and McClelland \& Stewart.

BRICUP [British Committee for Universities for Palestine]. Retrieved from http://www.bricup.org..uk/

Campell, M. (1995). Stories of the road allowance people. With paintings by Sherry Farrell Racette. Penticton, BC: Theytus Books.

Canadians for Peace and Justice in the Middle East. Gaza photo expo threatened with closure. Retrieved from http://www.cjpme.org./display document.aspx ?DocumentID $=6798$ Savemode $=0$

CAUT. Policy statement on academic freedom. Retrieved from http://www.caut.ca/pages.asp?page=611\&lang=1

CAUT. Policy statement on academic freedom and artistic expression. Retrieved from http://www.caut.ca/pages.asp?page=6\&lang1

CAUT. Statement on Gaza conflict. Retrieved from http://www.caut.ca?pages.asp?page=764

Cohen, M. (2010, February 24). Montreal French community upset by controversial photo Gaza exhibit. Jewish Tribune.

Drumond, S. G. Contemplating Israel/Palestine as one state: A case study in the fragility of academic freedom. Under consideration by University of Toronto Press. Retrieved from http://www.fragilefreedomatyorku.ca/content/

Doumani, B. (Eds.) (2008). Academic freedom after September 11. New York, NY: Zone Books.

Findlay, L. M. (2009). Can the institution speak? The University as testimony in Canada today. Humanities Review, 15(3), pp. 11-26.

Gilmour, J., Imai, S. \& Van Harten, G (n.d). Letter to the York University Senate. Osgoode Hall Faculty Association Executive. Retrieved from http://www.fragilefreedomatyorku.ca/blog/

Graff, G. (1992). Beyond the culture wars: How teaching the conflicts can revitalize American education. New York, NY: Norton. 
Huizinga, J. (1970). Homo ludens: A study of the play element in culture. London, UK: M. T. Smith.

Iacobucci, F. (2010). The mapping conference and academic freedom: A report to President Mamdouh Shoukri. Retrieved from http://www.yorku.ca/acreview/iacobbucci_report.pdf

Kant, I. (1979). The conflict of the faculties: Der Streit der Fakultäten. New York, NY: Abaris Books.

Martel, Y. (2010). Beatrice \& virgil. Toronto, ON: Knopf Canada.

Judgements of the Supreme Court of Canada. (1990). McKinney vs. U of Guelph..Retrieved from http://lexum.umontreal.ca/en/1990/1990scr3-229.html

McLeod, N., (2010). Rethinking Indigenous history: James Henderson's paintings as mnemonic icons. In D. Ring \& N. McLeod (Eds.), James Henderson: Wicite owapi wicasa/The man who paints the old men (pp. 55-68). Curated by Dan Ring and Neal McLeod. Saskatoon, SK: Mendel Art Gallery..

Mearsheimer, J. \& Walt, S. (2007). The Israeli lobby and the U.S. foreign policy. New York: Farrar, Straus and Giroux

Metson, G., \& Lean, C.. (1981). Alex Colville: Diary of a war artist. Halifax, NS: Nimbus Publishing.

Nelson, C., \& Watt, S. (1999). Academic keywords: A devil's dictionary for higher education. New York, NY: Routledge.

O’Malley, K. (2010, November 10). For the record: The full text of the Ottawa Protocol. Retrieved from http://www.cbc.ca/politics/insidepolitics/2010/11/for-the-record...

Pinchin, K. Israel-Palestine brouhaha at York rages on. Retrieved from http://oncampus.macleans.ca/education/2009.06/16...

Robinson, D. (2009). The status of higher education teaching personnel in Israel, the West Bank and Gaza. Ottawa, ON, \& Brussels, BG: Canadian Association of University Teachers and Education international.

Rogoff, I. (2000). Tera Infirma: Geography's visual culture. London, UK: Routledge.

Said, E. (2001). Power, politics, and culture: Interviews. New York, NY: Pantheon Books.

Said, E. (2004), From Oslo to Iraq and the road map: Essays. New York, NY: Vintage.

Silberstein, L.J. (Eds.). (1999). The postzionism debates: Knowledge and power in Israeli culture. New York, NY: Routledge.

Stoler, A.L. By colonial design. Retrieved from http://pulsemedia.org/2010/09/17/eminentscholar-ann-stoler-endorses-boycott-of-israel/

Thomson, J., Baird, P., \& Downie, J. (2001). The Olivieri Report. Toronto, ON: James Lorimer.

Walia, H. (2009, September 28). Really Harper, Canada has no history of colonialism? The Dominion: news from the grassroots. 